\title{
Boron Removal from Silicon by Humidified Gases
}

\author{
JAFAR SAFARIAN, KAI TANG, KJETIL HILDAL, and GABRIELLA TRANELL
}

Boron (B) is one of the most problematic impurities to remove from metallurgical grade silicon in the production of more pure solar grade silicon ( $\mathrm{SoG}-\mathrm{Si})$. In the present work, recent progresses in the application of reactive gases for B removal from molten silicon is reviewed. Moreover, in order to clarify the mechanisms and kinetics of gas-based B-refining, an experimental procedure using humidified $\mathrm{Ar}, \mathrm{N}_{2}$, and $\mathrm{H}_{2}$ gases applied to boron-doped silicon melt is described. It is shown that the kinetics and extent of $\mathrm{B}$ removal is depending on the type of humidified gas. The thermodynamics and kinetics of B removal from molten silicon are studied to explain experimental observations. The mass transfer coefficients of $\mathrm{B}$ are calculated and possible mechanisms for $\mathrm{B}$ removal by the reactive gases are proposed:

$$
\begin{aligned}
1 / 2 \mathrm{H}_{2}(\mathrm{~g}) & =\underline{\mathrm{H},} \\
\underline{\mathrm{B}}+\underline{\mathrm{H}}+\mathrm{H}_{2} \mathrm{O}(\mathrm{g}) & =\underline{\mathrm{HBO}(\mathrm{g})+\mathrm{H}_{2} .}
\end{aligned}
$$

It is shown that the lower equilibrium partial pressure of $\mathrm{HBO}$ gas at higher temperatures causes slower B removal rate.

DOI: $10.1007 / \mathrm{s} 40553-014-0007-8$

(c) The Minerals, Metals \& Materials Society and ASM International 2014

\section{INTRODUCTION}

SILICON is the main material used for the fabrication of solar cells and will likely continue to be a main material in photovoltaic industry for decades to come. The production of solar grade silicon (SoG-Si) through a metallurgical route is more energy efficient and environmentally benign than the traditional chemical route (Siemens process). Application of a gas refining technique could further improve the efficiency of a metallurgical refining process for low-boron SoG-Si. The removal of B from silicon by gas treatment has been studied by several researchers using plasma technique or gas blowing. The application of $\mathrm{H}_{2} \mathrm{O}$ gas in the reactive gas in plasma refining ${ }^{[1-6]}$ and $\mathrm{H}_{2}-\mathrm{H}_{2} \mathrm{O}$ gas mixtures through non-plasma-aided gas blowing ${ }^{[7,8]}$ has shown faster $\mathrm{B}$ removal compared to the application of pure $\mathrm{H}_{2},{ }^{[8-10]} \mathrm{O}_{2},{ }^{[9,11]}$ and $\mathrm{CO}_{2}{ }^{[11]}$ as reactive gases. The plasma refining experiments with $\mathrm{H}_{2}-\mathrm{O}_{2}$ mixtures ${ }^{[12,13]}$ as the reactive gas have also indicated faster $\mathrm{B}$ removal from silicon than using $\mathrm{H}_{2}, \mathrm{O}_{2}, \mathrm{CO}_{2}$ gases. This has been suggested to be due to the removal of $\mathrm{B}$ from silicon through the formation of volatile $\mathrm{H}-\mathrm{B}-\mathrm{O}$ species at the silicon melt surface, which is more favorable than formation of volatile $\mathrm{H}-\mathrm{B}$ and $\mathrm{B}-\mathrm{O}$ species. It has been

JAFAR SAFARIAN, Researcher, and KAI TANG, Senior Researcher, are with the SINTEF Materials and Chemistry, Alfred Getz Vei 2, 7465 Trondheim, Norway. Contact e-mail: Jafar.Safarian@ sintef.no KJETIL HILDAL, R\&D Engineer, is with the Process Development Group, ELKEM AS-Technology, Kristiansand, Norway. GABRIELLA TRANELL, Associate Professor, is with the Department of Materials Science and Engineering, Norwegian University of Science and Technology (NTNU), Alfred Getz Vei 2, 7491 Trondheim, Norway. Manuscript submitted October 4, 2013.

Article published online January 19, 2014 proposed that formation of $\mathrm{HBO}$ is more favorable than other species. ${ }^{[2,6]}$ Tang et al. ${ }^{[14]}$ has recently reported the changes in the Gibbs energy of formation of $\mathrm{HBO}(\mathrm{g})$ as:

$$
\begin{aligned}
& \mathrm{B}+1 / 2 \mathrm{H}_{2}+1 / 2 \mathrm{O}_{2}=\mathrm{HBO} \\
& \Delta G^{\circ}=-229.4-0.2029 T(\mathrm{~kJ} / \mathrm{mol}) .
\end{aligned}
$$

The mechanism of $\mathrm{HBO}$ formation in the silicon refining by $\mathrm{H}_{2} \mathrm{O}$ containing gases is still not well-known. Khattak et al. ${ }^{[2]}$ proposed that the removal of $\mathrm{B}$ at the melt surface occurs through reaction with the $\mathrm{SiO}$ and $\mathrm{H}_{2}$ gases as:

$$
\mathrm{SiO}(\mathrm{g})+1 / 2 \mathrm{H}_{2}(\mathrm{~g})+\underline{\mathrm{B}}=\mathrm{HBO}(\mathrm{g})+\mathrm{Si} .
$$

According to this study, the $\mathrm{SiO}$ gas in Reaction [2] is produced through the simultaneous oxidation of silicon with $\mathrm{H}_{2} \mathrm{O}$ to $\mathrm{H}_{2}$ and $\mathrm{SiO}$ gas. Altenberend ${ }^{[15]}$ introduced an enrichment factor, which is the ratio of $\mathrm{B}$ over $\mathrm{Si}$ in the gas phase, and reported that this factor is proportional to the square root of the $\mathrm{H}_{2}$ concentration in the gas. The kinetics of $\mathrm{B}$ removal is dependent on both the refining method and also the reactive gas composition. Reaction rate constants in the range $2 \times 10^{-5}$ to $1.4 \times 10^{-4} \mathrm{~m} / \mathrm{s}$ have been reported for $\mathrm{B}$ removal by different plasma techniques. ${ }^{[5]}$ The largest rate constants for plasma aided $\mathrm{B}$ removal have been achieved by applying Ar$1.24 \mathrm{pctH}_{2} \mathrm{O}$ and $\mathrm{Ar}-7.5$ pctH $_{2} \mathrm{O}^{[5]}$ reactive gases, resulting in rate constants as $1.4 \times 10^{-4}$ and $7.8 \times 10^{-4} \mathrm{~m} / \mathrm{s}$, respectively. Lower rate constants have been reported from the non-plasma-aided blowing of $\mathrm{H}_{2}-\mathrm{H}_{2} \mathrm{O}$ gas mixtures $\left(1.0 \times 10^{-6}\right.$ to $\left.1.3 \times 10^{-5} \mathrm{~m} / \mathrm{s}\right) \cdot{ }^{[7,8]}$ The highest rate constant for such conditions has been reported for $\mathrm{H} 2-3.2 \mathrm{pctH}_{2} \mathrm{O}$ at $1723 \mathrm{~K}\left(1450{ }^{\circ} \mathrm{C}\right) .{ }^{[8]}$ 
In the present study, the gas-based removal of B from molten silicon is studied experimentally. The obtained results are discussed based on thermodynamic and kinetic considerations of the refining system. These are used further to explain the mechanism of B removal by humidified gases.

\section{EXPERIMENTAL PROCEDURE}

Electronic grade polycrystalline silicon $(9 \mathrm{~N})$ was Bdoped by melting silicon in a graphite crucible in an induction furnace under Ar flow. The melt was kept for 1 hour at $1873 \mathrm{~K}\left(1600{ }^{\circ} \mathrm{C}\right)$, and cast in a water cooled copper mould to minimize B segregation. The prepared master Si-B alloy was analysed by a high resolution inductively coupled plasma mass spectrometry (ICPMS) and it showed B concentration as $430 \pm 10$ ppmw. Mixtures of this master alloy and the polycrystalline silicon were melted in graphite crucible with $75 \mathrm{~mm}$ inside diameter and $85 \mathrm{~mm}$ outside diameter for making B-containing silicon melts. Gas refining of the silicon melts was done in an induction furnace, the experimental setup is schematically shown in Figure 1. The furnace chamber was purged for oxygen through evacuation twice followed by argon (+99.999 pctAr) flushing. The heating and melting was then done under Ar flow, while the temperature at $10 \mathrm{~mm}$ above the crucible bottom was measured by a thermocouple type $\mathrm{C}$ located in an alumina insulating tube. Pure $\mathrm{Ar}, \mathrm{N}_{2}$, and $\mathrm{H}_{2}$ gases $(5 \mathrm{~N})$ were moisturized by a humidifier ( $\mathrm{P} 10$ series humidifier, Cellkraft AB, Stockholm, Sweden) and blown over a $400 \mathrm{~g}$ B-doped Si-melt with flow of $3 \mathrm{NL} / \mathrm{min}$ using a lance with $4 \mathrm{~mm}$ inner diameter from $40 \mathrm{~mm}$ above the melt surface. The accuracy of the humidifier was $1.5 \mathrm{pctRH}$ (relative humidity), a typical $\mathrm{RH}$ as 40 pct is obtained for $3 \mathrm{vol}$ pet $\mathrm{H}_{2} \mathrm{O}$ in $\mathrm{Ar}$ at $313 \mathrm{~K}\left(40^{\circ} \mathrm{C}\right)$. The partial pressure of oxygen in the outlet was continuously measured by an oxygen analyser (Rapidox 2100ZR Oxygen Analyser, Cambridge Sensotec Ltd., Cambridgeshire, UK), with a detection limit of $10^{-20}$ ppmw. There are ports and windows on the top of the furnace which make it possible to watch the melt surface and insert a quartz sampling tube. Watching the melt surface is beneficial to observe the formation of any condensed phases over the melt during the refining. Samples from the melt, each around $2 \mathrm{~g}$, were taken throughout the refining. Additional experimental details are shown in Table I. The silicon melt was cast after refining in the water cooled copper mould. Three parallels from each taken sample with around $30 \mathrm{mg}$ weight were analysed by ICP-MS to determine the concentration of $\mathrm{B}$. In addition to the ICP-MS analysis, the resistivity of the final cast silicon was measured by a Jandel 4 point probe (Jandel Engineering, Ltd., Bedfordshire, UK) and the corresponding B concentrations then determined according to the ASTM F723-99 standard for conversion between resistivity and

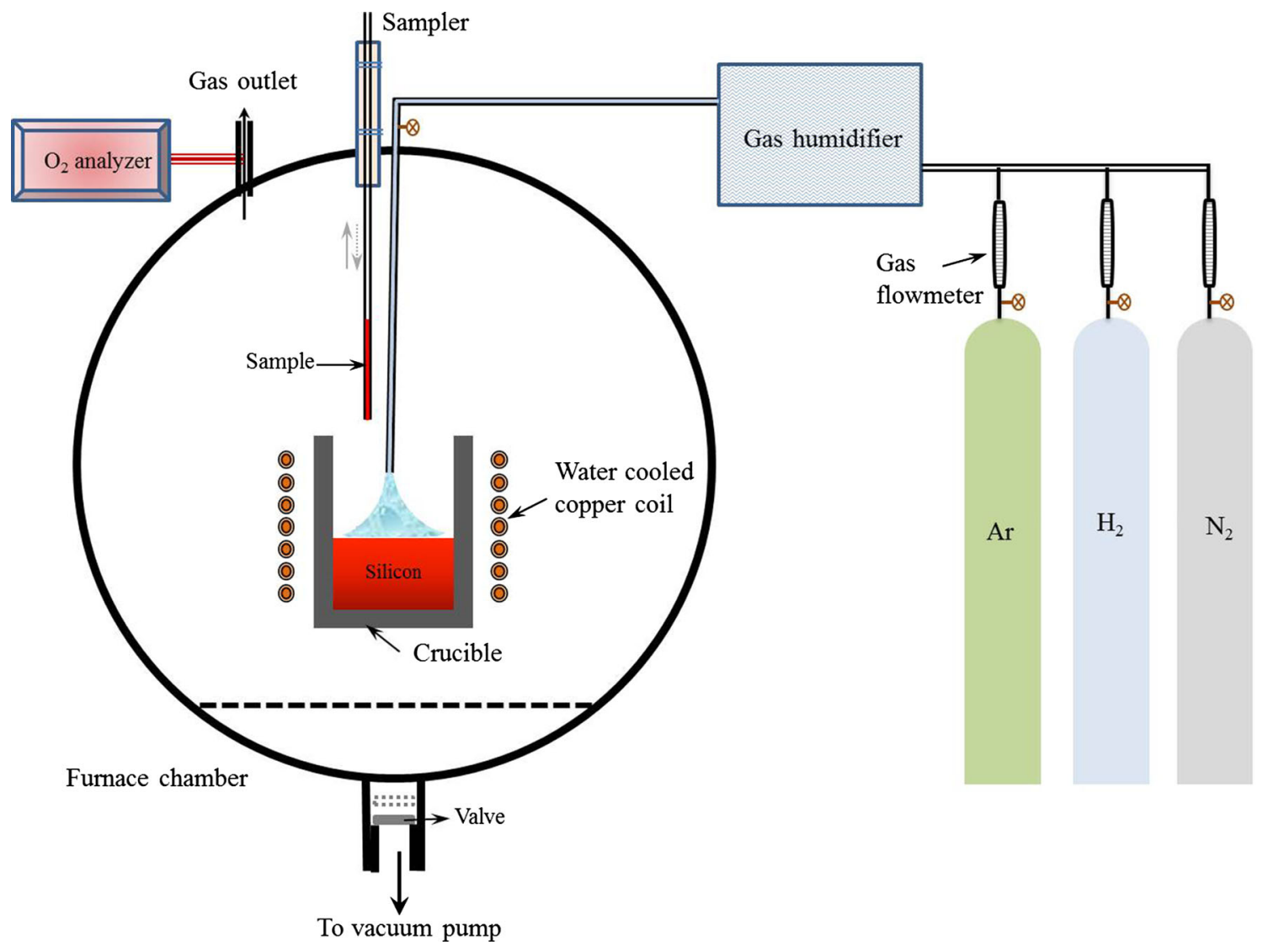

Fig. 1-Schematic of the experimental set up. 
Table I. Details of the Experiments and B Concentrations in Treated Silicon Melts

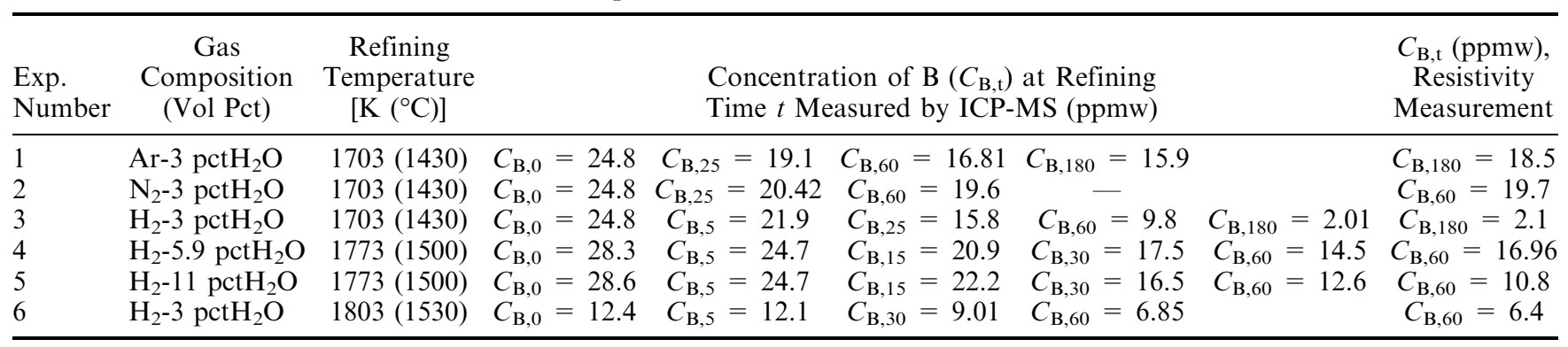

dopant density for B-doped silicon. It was found in the experiments that an oxide surface layer is formed over the silicon melt during refining. This surface layer was also analyzed by electron probe microanalysis (EPMA).

\section{RESULTS}

The obtained results from the experimental work are described as follows.

\section{A. Oxygen Partial Pressure}

The oxygen partial pressure in the gas outlet during the heating and refining were measured. It was observed that the oxygen partial pressure is rapidly decreasing in the furnace during heating with a highest rate at around $1273 \mathrm{~K}\left(1000{ }^{\circ} \mathrm{C}\right)$ to very low partial pressures, i.e., $1 \times 10^{-14} \mathrm{ppm}$. This decrease in oxygen partial pressure is due to the fast interaction of oxygen with the graphite crucible with increasing temperature and $\mathrm{CO}$ gas formation. The oxygen partial pressure is significantly reduced during heating with a short rise in $p_{\mathrm{O} 2}$ at the start of melting and subsequent decrease during the refining step with the introduction of humidified gases. This shows that free oxygen in the gas phase during the refining process is at a very low level. The oxygen partial pressure is levelled off after some refining time. The observed oxygen partial pressures for all the experiments were below $1 \times 10^{-17} \mathrm{ppm}$ during the main gas blowing cycle. When humidified $\mathrm{Ar}$ and $\mathrm{N}_{2}$ were used, the oxygen partial pressures were mostly between $1 \times 10^{-17}$ and $1 \times 10^{-18}$ ppm, while when humidified $\mathrm{H}_{2}$ was used $p \mathrm{O}_{2}$ decreased to below $1 \times 10^{-20} \mathrm{ppm}$; the detection limit of the oxygen gas analyzer.

\section{B. Boron Removal from Silicon Melts}

The measured chemical compositions of silicon samples presented in Table I show B removal from silicon for all the experiments. The measured B concentrations by the resistivity method are in relatively good agreement with the ICP-MS analysis. In order to evaluate the effectiveness of the refining conditions on the $\mathrm{B}$ removal, the degree of $\mathrm{B}$ removal was calculated as:

$$
F_{\mathrm{B}}=100 \times\left(1-C_{\mathrm{B}, \mathrm{t}} / C_{\mathrm{B}, 0}\right),
$$

where $C_{\mathrm{B}, 0}$ is the initial concentration of $\mathrm{B}$ in silicon and $C_{\mathrm{B}, \mathrm{t}}$ is the concentration of $\mathrm{B}$ at refining time $t$. It is worth mentioning that the silicon loss during the refining is not significant, a few weight percentages, i.e., 3 pct, and it does not affect the above definition for $\mathrm{B}$ removal. The results (Figure 2) show that for all experiments B is removed with an initial high rate stage followed with a second slower stage. For a given refining time, i.e., 60 minutes, the $\mathrm{B}$ removal degree by using $\mathrm{H}_{2}-\mathrm{H}_{2} \mathrm{O}$ gas mixtures is higher than that for $\mathrm{Ar}-\mathrm{H}_{2} \mathrm{O}$ and $\mathrm{N}_{2}-\mathrm{H}_{2} \mathrm{O}$ gases. The rate and extent of $\mathrm{B}$ removal for a given steam concentration, 3 pct $\mathrm{H}_{2} \mathrm{O}$, is highest when humidified $\mathrm{H}_{2}$ is used, and lowest for $\mathrm{N}_{2}-3$ pct $\mathrm{H}_{2} \mathrm{O}$. The $\mathrm{B}$ removal rates by $\mathrm{H}_{2}-\mathrm{H}_{2} \mathrm{O}$ gases with higher moisture concentrations $\left(5.9\right.$ pct $_{2} \mathrm{O}$ and 11 pct $\left.\mathrm{H}_{2} \mathrm{O}\right)$ at $1773 \mathrm{~K}\left(1500{ }^{\circ} \mathrm{C}\right)$ are more or less the same as for a temperature of $1703 \mathrm{~K}\left(1430^{\circ} \mathrm{C}\right)$ for 3 pct $\mathrm{H}_{2} \mathrm{O}$ at initial, independent of $\mathrm{H}_{2} \mathrm{O}$ content in the experiments in this study. Longer refining times, however, they show different behavior and the $\mathrm{B}$ removal kinetics is slower for 5.9 and 11 pct $\mathrm{H}_{2} \mathrm{O}$ concentrations. For a given gas phase composition as $\mathrm{H}_{2}-3$ pct $\mathrm{H}_{2} \mathrm{O}$, the kinetics of $\mathrm{B}$ removal is slower at higher temperature as clearly seen through comparing the Experiments 3 and 6.

\section{Analysis of the Passive Surface Layer}

As earlier mentioned, the formation of a passive oxide layer on the silicon melt surface was observed during the silicon refining in some experiments. Figure 3 shows a cross section of the passive surface layer formed over Si$\mathrm{B}$ melt treated by $\mathrm{H}_{2}-3$ pct $\mathrm{H}_{2} \mathrm{O}$ gas. This layer covered a part of the surface after $1 \mathrm{~h}$ of refining time. This cross section shows a very good contact between the layer and silicon. This layer is $\mathrm{SiO}_{2}$ and it is porous with regard to the presented X-ray map of the elements. It is worth mentioning that for the majority of the experiments, except Exp. 2 and Exp. 6, this passive oxide layer was observed after around 30 minutes.

\section{DISCUSSION}

\section{A. Kinetics of B Removal}

Assuming first order reaction kinetics for the removal of B from liquid silicon, the relationship between the B concentration and refining time $t$ can be written as:

$$
\ln \left(C_{\mathrm{B}, 0} / C_{\mathrm{B}, \mathrm{t}}\right)=k_{\mathrm{B}}(A / V) t
$$

where $A / V$ is the ratio of melt surface over the melt volume, and $k_{\mathrm{B}}$ is the total mass transfer coefficient for 


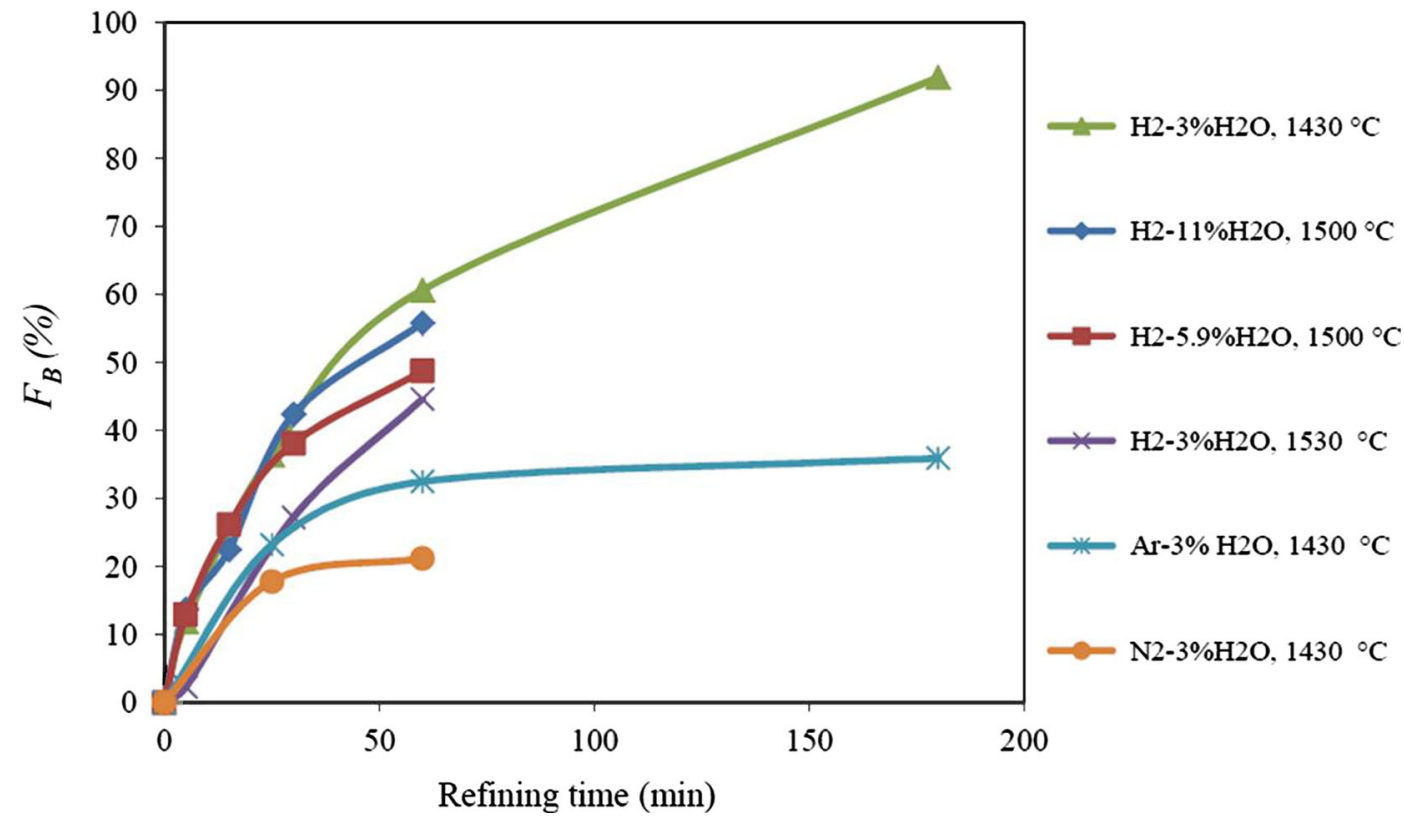

Fig. 2-Boron removal degree in silicon refining by humidified gases.

$B$ removal from the melt to the gas phase. The value of $k_{\mathrm{B}}$ is the slope of a plotted line of the left side of Eq. [4] against $(A / V) t$ as illustrated in Figure 4. For calculating $k_{\mathrm{B}}$ we may consider the first 30 minutes of refining due to the negligible amount of passive surface layer formation within this refining time. This yields $k_{\mathrm{B}}=7 \times 10^{-6}, 6 \times 10^{-6}, \quad 1.3 \times 10^{-5}, \quad 1.4 \times 10^{-5}$, $1.3 \times 10^{-5}$, and $7 \times 10^{-6} \mathrm{~m} / \mathrm{s}$ for Experiments 1 to 6 , respectively.

The removal of B from silicon occurs through a first order reaction as seen for Experiment 6 for the whole refining time due to no formation of the passive oxide layer. The slower B removal for other experiments after some refining time is due to the formation of this layer decreasing the effective $A / V$ ratio. The $\mathrm{SiO}_{2}$ layer plays an important role in the refining kinetics; it is formed at lower temperatures and higher oxygen potential by a passive silicon oxidation scheme:

$$
\mathrm{Si}+\mathrm{H}_{2} \mathrm{O}(\mathrm{g})=\mathrm{SiO}_{2}(\mathrm{~s})+\mathrm{H}_{2} .
$$

The oxide layer was observed for Exp. 3 after 1 hour refining. For Exp. 4 and Exp. 5, which were carried out at a higher temperature and higher $\mathrm{H}_{2} \mathrm{O}$ contents, it was observed after 30 minutes refining; i.e., the application of a higher steam concentration provided more favorable thermodynamic conditions for the formation of $\mathrm{SiO}_{2} \cdot{ }^{[16]}$ In Exp. 6 with $100 \mathrm{deg}$ higher temperature compared to Exp. 3, no oxide layer was observed and it may be concluded that for a given $\mathrm{H}_{2} \mathrm{O}$ content in the gas, the passive layer is less stable at higher temperatures, which is in accord with thermodynamic calculations. Predicting that at higher temperatures, the stability of $\mathrm{SiO}$ gas is increased and may hence postpone the formation of the passive oxide layer.

\section{B. Mechanism of B Removal}

The removal of $\mathrm{B}$ by the humidified gases can potentially take place according to the following oxidation reaction:

$$
\underline{\mathrm{B}}+\mathrm{H}_{2} \mathrm{O}(\mathrm{g})=\mathrm{HBO}(\mathrm{g})+1 / 2 \mathrm{H}_{2} .
$$

Simultaneously, the oxidation of silicon to $\mathrm{SiO}$ gas is taking place in the system:

$$
\begin{aligned}
\mathrm{Si}(\mathrm{l})+\mathrm{H}_{2} \mathrm{O}(\mathrm{g})=\mathrm{SiO}(\mathrm{g})+\mathrm{H}_{2}(\mathrm{~g}) & \\
\Delta G^{\circ}= & 84.2-0.103 T[1700 \mathrm{~K} \text { to } 2300 \mathrm{~K} \\
& \left.\left(1427^{\circ} \mathrm{C} \text { to } 1154^{\circ} \mathrm{C}\right)\right] .
\end{aligned}
$$

The $\mathrm{B}$ removal rate is increased with increasing $\mathrm{H}_{2} \mathrm{O}$ content in the refining gases ${ }^{[7,14]}$ as long as the passive oxide layer is not covering the surface. In parallel, more $\mathrm{SiO}$ gas is produced with higher $\mathrm{H}_{2} \mathrm{O}$ contents in the refining gases due to maintaining larger driving force for the Reaction [7]. On the other hand, more $\mathrm{SiO}$ gas is produced at higher temperatures with regard to the changes of $\Delta G^{\circ}$ with temperature for Reaction [7]. Hence, increasing the refining temperature has to increase the kinetics of B removal, if Reaction [2] is the controlling step of B removal. However, the results of this work and the previous works ${ }^{[8,15]}$ show that the rate of B removal is decreased with increasing temperature and Reaction [2] cannot explain the effect of temperature. If we assume that Reaction [6] is the main reaction for $\mathrm{B}$ removal, and that $\mathrm{H}_{2}$ does not play a role in the removal kinetics, it is difficult to explain the difference in $\mathrm{B}$ removal rate with gas composition change in experiments 1,2 , and 3 where the steam concentration in the reactive gas phase is the same, while 

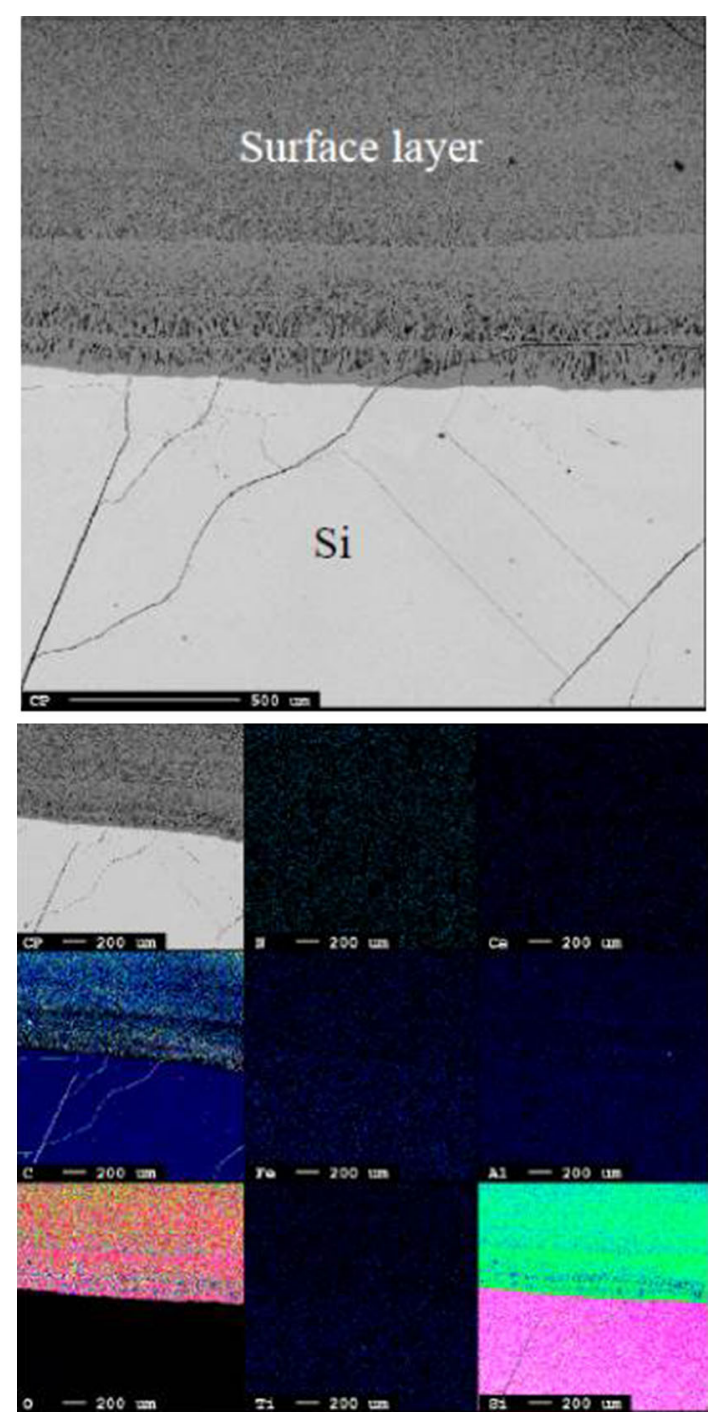

Fig. 3-Interfacial area between silicon and the passive oxide layer taken by EPMA.

the carrier gas different ( $\mathrm{Ar}, \mathrm{N}_{2}, \mathrm{H}_{2}$, respectively). According to the present results and the previous work at NTNU, ${ }^{[8]}$ the $\mathrm{B}$ removal rate is higher than any other type of gas when $\mathrm{H}_{2}-\mathrm{H}_{2} \mathrm{O}$ mixtures are used. Therefore, we may conclude that hydrogen plays a key role in the reaction mechanism as observed in literature as well. ${ }^{[5,12]}$ We propose that there may be two different, potentially both contributing mechanisms to this result; the first mechanism is that hydrogen is dissolved in silicon and that $\mathrm{B}$ removal occurs through the interaction of the dissolved $\mathrm{B}$ and $\mathrm{H}$ species with $\mathrm{H}_{2} \mathrm{O}$ gas at the melt-gas interfacial area:

$$
\begin{gathered}
1 / 2 \mathrm{H}_{2}(\mathrm{~g})=\underline{\mathrm{H}}, \\
\underline{\mathrm{B}}+\underline{\mathrm{H}}+\mathrm{H}_{2} \mathrm{O}(\mathrm{g})=\mathrm{HBO}(\mathrm{g})+\mathrm{H}_{2} .
\end{gathered}
$$

Hence the process requires considerable amount of hydrogen to provide enough dissolved atomic hydrogen close to the reaction interface for Reaction [9]. This

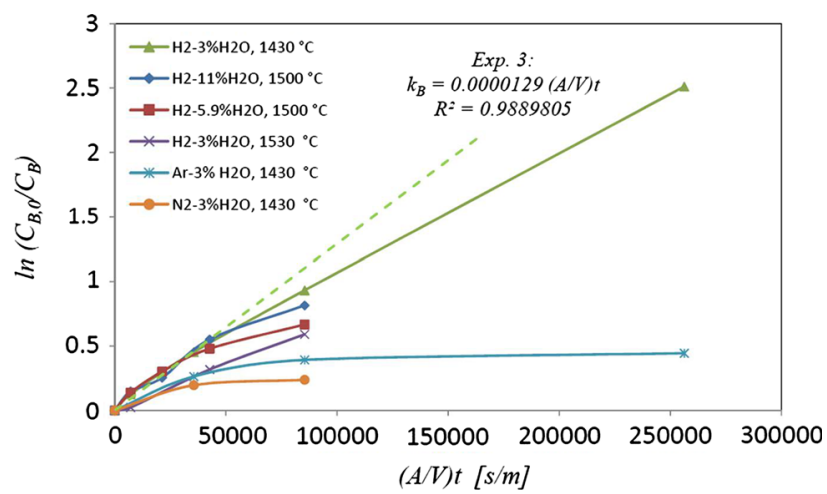

Fig. 4-The relationship between the concentration of $\mathrm{B}$ in the melt and time considering a first order reaction.

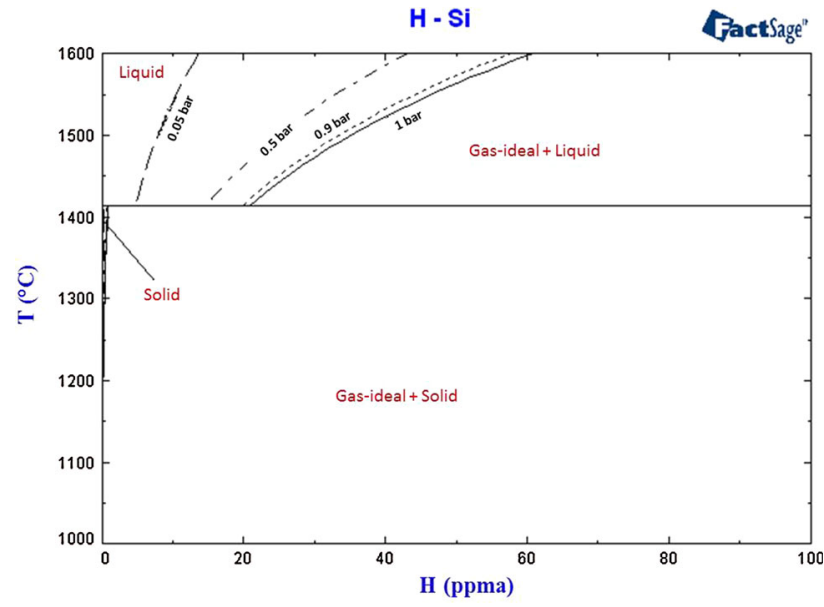

Fig. 5-Silicon-rich part of the Si-H binary phase diagram.

mechanism may explain the faster $\mathrm{B}$ removal with increasing the $\mathrm{H}_{2} /$ Ar ratio in Ar- $\mathrm{H}_{2}-\mathrm{H}_{2} \mathrm{O}$ gas mixtures. ${ }^{[8]}$ When $\mathrm{H}_{2}$ gas is not purged into the system, i.e., Experiments 1 and 2, the $\mathrm{B}$ removal occurs through the dissociation of $\mathrm{H}_{2} \mathrm{O}$ at the melt surface into $\mathrm{H}$ and $\mathrm{O}$ elements and further $\mathrm{B}$ removal by Reaction [9]. Obviously, the rate of $\mathrm{B}$ removal in this mechanism will be slower than $\mathrm{H}_{2}-\mathrm{H}_{2} \mathrm{O}$ mixtures due to much lower dissolved hydrogen in the melt.

In order to study the hydrogen solubility in silicon, the binary $\mathrm{Si}-\mathrm{H}$ system was studied using the developed database for SoG-Si at SINTEF/NTNU ${ }^{[17]}$ and applying the FactSage thermodynamic software. The Si-rich part of the phase diagram at elevated temperatures is shown in Figure 5 and it shows that at the applied refining temperatures there are significant $\mathrm{H}$ solubility in silicon. For instance at $1703 \mathrm{~K}\left(1430{ }^{\circ} \mathrm{C}\right)$ around 25 ppma hydrogen exist in the melt at $1 \mathrm{~atm}$ pressure. It is worth mentioning that higher solubility of $\mathrm{H}$ in silicon as 60 ppma has been measured by experimental study by Ikari et al. ${ }^{[18]}$ for the temperature range of $1703 \mathrm{~K}$ to $1773 \mathrm{~K}\left(1430{ }^{\circ} \mathrm{C}\right.$ to $\left.1500^{\circ} \mathrm{C}\right)$. Hence, there is always considerable amount of dissolved hydrogen in the melt surface during the $\mathrm{B}$ elimination to very low levels. The high solubility of $\mathrm{H}_{2}$ in silicon was also 
confirmed in the present study. As shown in Figure 6, the formation of many pores in the solidified silicon under $\mathrm{H}_{2}$ atmosphere indicates the presence of dissolved hydrogen in the melt. The solubility of hydrogen in solid silicon is much less than liquid silicon (Figure 5) and it causes the formation of $\mathrm{H}_{2}$ bubbles during solidification.

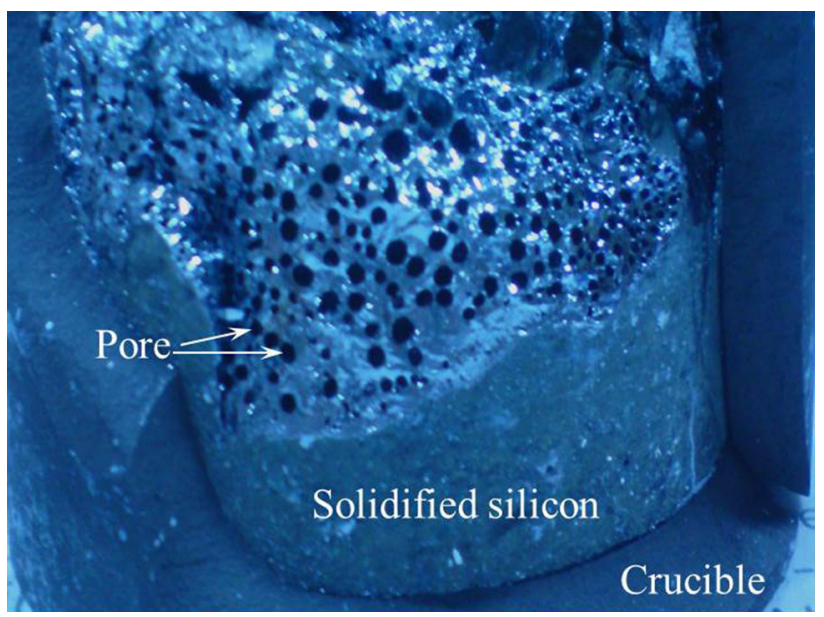

Fig. 6-Porous feature of solidified silicon in graphite crucible under $\mathrm{H}_{2}$ atmosphere.
In the present study, a graphite crucible was used to contain the silicon which results in carbon saturation of the melt. The high activity of carbon in the melt, in addition to dissolved hydrogen, ensures a low solubility of oxygen. In addition, the low partial pressure of oxygen in the gas (i.e., $10^{-18} \mathrm{ppm}$ ) makes the availability of oxygen limited. As we did not observe significant effect of increasing the $\mathrm{H}_{2} \mathrm{O}$ content in the $\mathrm{H}_{2}-\mathrm{H}_{2} \mathrm{O}$ gas mixtures (above 3 vol pct) on $\mathrm{B}$ removal kinetics at initial stages, we do not consider dissolved oxygen a major contributor in the $\mathrm{B}$ removal reaction mechanism. More experimental work may clarify more details about the role of dissolved oxygen in the reaction mechanism.

In addition to the role of dissolved hydrogen on the kinetics of the $\mathrm{B}$ removal, other researchers ${ }^{[15]}$ have suggested that the presence of $\mathrm{H}_{2}$ suppresses the formation of condensed $\mathrm{SiO}_{2}$ by oxidation of $\mathrm{SiO}$ in the gas boundary layer, hence enhancing the diffusion rate of $\mathrm{HBO}$ products. Given that the $p_{\mathrm{O} 2}$ in the $\mathrm{H}_{2}$ containing gases used in the present study was below the detection limit, allowing less oxygen in the gas phase as compared to $\mathrm{N}_{2}$ and Ar carried gases, this is also a possible contributing factor to the increased removal rate for $\mathrm{H}_{2}$ carried gases.

The thermodynamic equilibrium in the system for refining of silicon melt containing 30 ppmw B by Ar3 pct $\mathrm{H}_{2} \mathrm{O}, \mathrm{N}_{2}-3$ pct $\mathrm{H}_{2} \mathrm{O}, \mathrm{H}_{2}-3$ pct $\mathrm{H}_{2} \mathrm{O}$ gases was studied through calculations using the FactSage thermody-

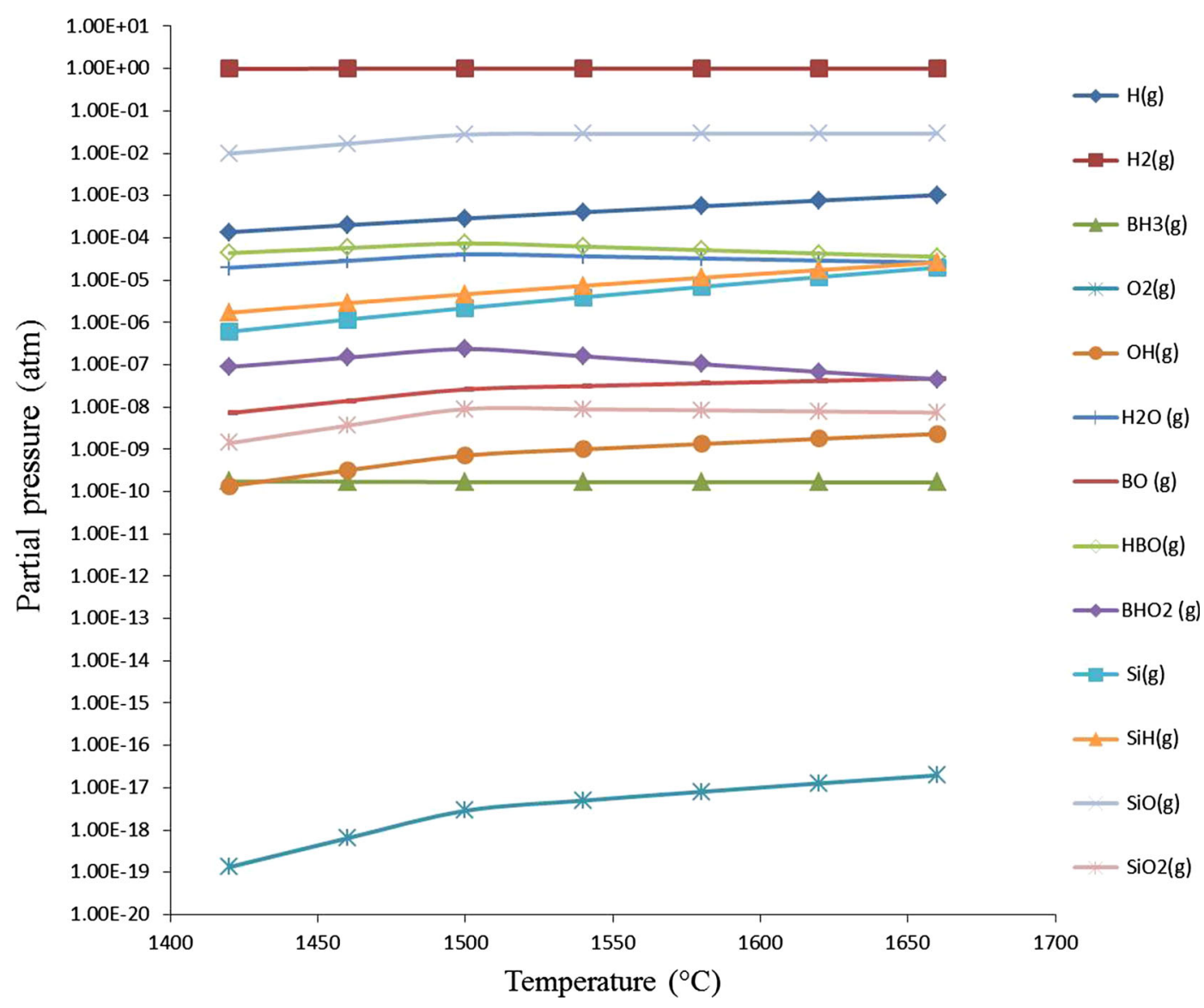

Fig. 7-Equilibrium partial pressures of gas components above a $400 \mathrm{~g}$ silicon melt containing 30 ppmw B under $\mathrm{H}_{2}-3$ pct $\mathrm{H}_{2} \mathrm{O}$ atmosphere. 
namic software, with the recently developed data base for solar grade silicon at SINTEF/NTNU. The results for the melt treatment at different temperatures for $\mathrm{H}_{2}-$ $3 \mathrm{pctH}_{2} \mathrm{O}$ are shown in Figure 7. It is seen that among the $\mathrm{B}$-containing species the partial pressure of $\mathrm{HBO}$ gas is the highest in the system and $\mathrm{B}$ removal through the formation of $\mathrm{HBO}$ is the most possible reaction. The thermodynamics calculations show very low oxygen partial pressures, which is in agreement with the measured low oxygen partial pressures by the oxygen analyzer in this work. The thermodynamic calculations indicated the existence of solid $\mathrm{SiO}_{2}$ in the system, although significant amount of $\mathrm{SiO}$ gas co-exists. We may propose that the reason of not observing a passive oxide layer $\left(\mathrm{SiO}_{2}\right)$ for some experiments is due to the lack of solid $\mathrm{SiO}_{2}$ nucleation on the silicon surface. This explanation may be supported by the observation of an oxide layer after some refining time, i.e., 30 minutes, and not from the start of gas blowing. Relatively fast oxide layer growth after nucleation may indicate thermodynamic stability of $\mathrm{SiO}_{2}$ in the system. The higher stability of $\mathrm{SiO}$ gas at higher temperatures may reduce the possibility of $\mathrm{SiO}_{2}$ layer formation, which is clearly seen through comparing Experiments 3 and 6. We may propose that when $\mathrm{N}_{2}$ gas is used, i.e., Experiment 2, it affects the interfacial energies between the liquid silicon and gas so that the nucleation of solid $\mathrm{SiO}_{2}$ becomes more difficult and this postpones or even stops the formation of solid $\mathrm{SiO}_{2}$ on the surface.

The slower B removal rate at higher temperatures can now be explained considering the thermodynamic equilibrium. Figure 7 shows that the equilibrium partial pressure of the $\mathrm{HBO}$ gas is decreased with increasing temperature. According to kinetic principles, this means smaller driving force for the chemical Reaction [9] at the melt surface and therefore a lower B removal rate. This is important from practical point of view in choosing the process temperature.

In order to study the importance of the mass transport in the melt and the gas phases, more experimental work with changing the process conditions, i.e., gas velocity, gas composition, and so forth are required.

\section{CONCLUSIONS}

The removal of $\mathrm{B}$ from molten silicon by humidified Ar, $\mathrm{N}_{2}$, and $\mathrm{H}_{2}$ gases was studied. It was found that $\mathrm{H}_{2}-$ $\mathrm{H}_{2} \mathrm{O}$ gas mixtures were most effective for $\mathrm{B}$ removal compared to the other gas mixtures investigated. Furthermore, the kinetics of $\mathrm{B}$ removal was faster at lower temperatures. A mass transfer coefficient for B removal by $\mathrm{H}_{2}-3 \mathrm{pctH}_{2} \mathrm{O}$ as $k_{\mathrm{B}}=1.3 \times 10^{-5} \mathrm{~m} / \mathrm{s}$ at $1703 \mathrm{~K}$ $\left(1430{ }^{\circ} \mathrm{C}\right)$ was obtained. Based on the experimental observations and thermodynamics of the system, it was proposed that B removal from silicon is taking place through simultaneous hydrogen dissociation into the melt and boron conversion into $\mathrm{HBO}$ gas by the dissolved hydrogen and $\mathrm{H}_{2} \mathrm{O}$ gas at the melt-gas interface. The presence of $\mathrm{H}_{2}$ in the refining gas may also suppress the $\mathrm{SiO}$ oxidation in the gas boundary layer, avoiding condensed species and hence enhancing the diffusion of $\mathrm{HBO}$ product with a subsequent increase in the $\mathrm{B}$ removal rate. The rate of $\mathrm{B}$ removal from molten silicon is decreased with increasing temperature due to the smaller equilibrium partial pressure of $\mathrm{HBO}$ gas and lowering the driving force of the chemical reaction of $\mathrm{B}$ removal at the melt-gas interfacial area.

\section{REFERENCES}

1. T. Ikeda and M. Maeda: Mater. Trans., 1996, vol. 37, pp. 983-87.

2. Khattak C.P., Joyce D.B., and Schmid F.: Report NREL/SR-52027593, National Renewable Energy Laboratory, 1999.

3. C.P. Khattak, D.B. Joyce, and F. Schmid: Sol. Energy Mater. Sol. Cells, 2002, vol. 74, pp. 77-89.

4. N. Yuge, M. Abe, K. Hanazawa, H. Baba, N. Nakamura, Y. Kato, Y. Sakaguchi, S. Hiwasa, and F. Aratani: Prog. Photovolt. Res. Appl., 2001, vol. 9, pp. 203-209.

5. N. Nakamura, H. Baba, Y. Sakaguchi, and Y. Kato: Mater. Trans., 2004, vol. 45 (3), pp. 858-64.

6. J.J. Wu, W.H. Ma, Y.N. Dai, and K. Morita: Trans. Nonferr. Met. Soc. China, 2009, vol. 19, pp. 463-67.

7. H.C. Theuerer: J. Metals, 1956, vol. 8, pp. 1316-39.

8. E. Nordstrand and M. Tangstad: Metall. Mater. Trans. B, 2012, vol. 43B, pp. 814-22.

9. S. Tsao and S.S. Lian: Mater. Sci. Forum, 2005, vols. 475-479, pp. 2595-98.

10. S. Rousseau, M. Benmansour, D. Morvan, and J. Amouroux: Sol. Energy Mater. Sol. Cells, 2007, vol. 91, pp. 1906-15.

11. K. Suzuki, K. Sakaguchi, T. Nakagiri, and N. Sano: J. Jpn. Inst. Met., 1990, vol. 54, pp. 161-67.

12. C. Alemany, C. Trassy, B. Pateyron, K.-I. Li, and Y. Delannoy: Sol. Energy Mater. Sol. Cells, 2002, vol. 72, pp. 41-48.

13. E. Fourmond, C. Ndzogha, D. Pelletier, Y. Delannoy, C. Trassy, Y. Caratini, Y. Baluais, and R. Einhaus: 19th European Photovoltaic Solar Energy Conference, Paris, France, 7-11 June, 2004.

14. K. Tang, S. Andersson, E. Nordstrand, and M. Tangstad: JOM, 2012, vol. 64 (8), pp. 952-56.

15. J. Altenberend: Ph.D. Thesis, Universite de granoble, 2012.

16. C. Wagner: J. Appl. Phys., 1958, vol. 29, pp. 1295-97.

17. K. Tang, E.J. Øvrelid, G. Tranell, and M. Tangstad: 12th International Ferroalloys Congress, June 6-9, Helsinki, Finland, 2010, pp. 619-29.

18. A. Ikari, H. Sasaki, E. Tokizaki, K. Terashima, and S. Kimura: Jpn. J. Appl. Phys., 1995, vol. 34 (8), pp. L1017-19. 